\title{
Non-cratonic garnet peridotites from rifted continental settings in Vitim, Siberia (Baikal Rift) and East Antarctica (Lambert-Amery Rift)
}

\author{
Foley, S.F. ${ }^{1}$, Glaser, S.M ${ }^{1}$. and Andronikov, A.V. ${ }^{1,2}$
}

1. Mineralogisch-Petrologisches Institut, Universität Götingen, Goldschmidtsr.1, D-37077 Göttingen, Germany

2. VNIIOkeangeologia, Abgliyski Ave. 1, 190121 St.Petersburg, Russia

Garnet peridotites form the dominant rock type in cratonic mantle xenolith suites carried by kimberlites, but are very rare in non-cratonic xenolith suites hosted by alkali basaltic volcanics. This presumably indicates that the generation of alkali basaltic and basanitic host lavas of most non-cratonic spinel lherzolite xenolith suites is too shallow to sample garnet peridotites, and that exceptional tectonic circumstances are required to permit sampling in the garnet stability field. These rare garnet peridotite occurrences are important, as they manifest relatively fertile major element compositions, and appear to confirm the compositional difference between cratonic and non-cratonic mantle lithosphere recognised on the basis of the abundant spinel lherzolite samples.

The examples of non-cratonic garnet peridotites which have been described to date appear to be either in a behind-arc setting in volcanics triggered by asthenospheric upwelling in response to subduction, such as those at Mingxi and Xilong in southeastern China (Cao and Zhu, 1987) and at Pali Aike in southern South America (Stern et al., 1989), or they occur in distal expressions of rift-related volcanism on the flanks of continental rifts, such as the Vitim Plateau in Transbaikalia, eastern Siberia (Ionov et al., 1993).

On the basis of new studies of in-situ trace element compositions of garnet- and spinel-peridotites from the Vitim Plateau (Glaser et al., 1998) and a thorough study of garnet- and spinel-peridotites from the northern end of the Lambert-Amery rift in eastern Antarctica (Andronikov et al., 1998), we describe here common features of rift-related garnet-peridotites, including episodic meit infiltration features resulting from earlier melt production in the developing rift. These occurrences of rift-related garnet peridotites were both sampled by alkali picrite magmas, whereas the back-arc examples occur in much $\mathrm{Mg}$-poorer alkaline volcanics. The generation of the alkali picrites can also be related to processes in the developing rift.

\section{Garnet-bearing peridotites of the Bereya Quarry, Vitim Plateau, Siberia}

The Vitim Plateau basaltic province is situated $\approx 250 \mathrm{~km}$ east of central Lake Baikal and, like a group of Cenozoic-Quaternary basalt fields $600-900 \mathrm{~km}$ away to the south and south-west of the lake, is related to the Baikal rift. Several localities are known from the Vitim Plateau in which garnet peridotites occur subordinately to spinel lherzolites (Ashchepkov et al., 1994), and one where garnet-bearing lherzolites dominate, forming $80 \%$ of the xenolith population. This is the Bereya quarry, previously referred to as "tuff-pit" by Ionov et al. (1993), in which the xenoliths are hosted by an alkaline picrite tuff with 14.5-17.4\% $\mathrm{MgO}, 1.0-2.0 \% \mathrm{~K}_{2} \mathrm{O}$ and 0.57-0.81\% $\mathrm{Na}_{2} \mathrm{O}$ (Ashchepkov, 1991).

Garnet peridotites from Bereya were previously described by Ionov et al. (1993). We have found similar garnet lherzolites in which spinel occurs only as inclusions in garnet and others with more spinel in which spinel occurs outside garnet, generally as inclusions in clinopyroxene, but we have also found more evidence of metasomatic enrichment. Amphibole occurs predominantly in veins (Ionov et al., 1993), and as a disseminated phase in spinel lherzolites. Phlogopite occurs in the veins and also in garnet lherzolites. Additionally, one strongly sheared spinel lherzolite with a glass-bearing mosaic texture was found, but does not show the enrichment of $\mathrm{Fe}$ and $\mathrm{Ti}$ that is characteristic of sheared peridotites in kimberlites.

Three types of reaction could be distinguished petrographically within the xenoliths: (1) Replacement of spinel, opx and cpx by garnet and olivine, which is probably a result of isobaric cooling close to 
the spinel-/garnet- peridotite transition pressure; (2) Reaction coronas between garnet and cpx as a result of cpx-introduction by infiltration of a silicate melt. The new cpx can also be found replacing former melt morphologies, defining apparent dihedral angles corresponding to melt/olivine/olivine junctions and much too small for equilibrium angles between three solid silicate phases; (3) Symplectite rims around garnet and glassy rims around individual cpx and amphibole crystals. These are unaffected by the identity of neighbouring phases and are commoner close to the edge of xenoliths, and so are interpreted as being due to melting caused by heating and decompression in the host magma.

Laser-ICP-MS analysis of all constituent minerals with ablation crater diameters of $40-80 \mu \mathrm{m}$ failed to detect significant zonation in trace elements even in cases with petrographic evidence for melt infiltration. However, microchemical support for melt infiltration is present in the form of trace element disequilibrium between minerals: calculation of trace element abundances in the infiltrating melt via experimental mineral/melt partitioning data sets shows the melt to have been similar to the host alkali picrite on the basis of cpx and amphibole analyses, whereas garnet shows a much less enriched pattern. This is consistent with incomplete re-equilibration of garnet with the infiltrating melt.

\section{Garnet-bearing peridotites from Jetty Peninsula, East Antarctica}

The Jetty Peninsula is situated adjacent to Beaver Lake at the northwestern end of the Lambert-Amery Rift close to the Amery Ice Shelf in eastern Antarctica. Garnet-spinel lherzolite xenoliths occur in two volatile-rich alkaline picrite intrusives of late Jurassic age (145-150 Ma), and were thus sampled during an intermediate stage of the long history of development of this large rift system. $\mathrm{MgO}$ contents of the picrites are 18.0-20.6\%, $\mathrm{K}_{2} \mathrm{O}=1.7-2.0 \%$ and $\mathrm{Na}_{2} \mathrm{O}=1.4-2.5 \%$. The intrusives occur together with ultramafic lamprophyres containng melilite and carbonates.

Petrographic and mineral chemical features of the Jetty Peninsula garnet-spinel lherzolites are summarised by Andronikov et al. (1998). Pertinent to the present discussion is the existence of a petrographic distinction between homogeneous spinel lherzolites (HSL). with depleted major element chemistry and inhomogeneous spinel lherzolites (ISL) which are variably re-enriched, reaching from samples as depleted as the HSL to apparently fertile compositions such as those of the garnet-spinel lherzolites (IGSL). Unlike the Bereya peridotites, the minerals in the Jetty Peninsula ISL and IGSL peridotites show distinct chemical zonation between cores and glass inclusion-rich rims. Further details of mineral chemistry are given by Andronikov et al. (1998).

\section{Similarites and differences between the Bereya and Jetty Peninsula garnet lherzolites}

The Bereya and Jetty Peninsula garnet peridotite localities have several characteristics in common, namely peripheral positions on the flanks of major continental rifts, alkali-picrite host magmas, both spinel- and garnet-bearing peridotite parageneses, and strong petrographic and chemical evidence for episodes of infiltration by silicate melts in the upper mantle.

Geophysical studies of the Baikal rift show the Vitim Plateau to be situated directly to the southeast of a sharp increase in lithosphere thickness, where the lithosphere is between 110 and $130 \mathrm{~km}$ thick. This feature is defined by an anomalous mantle layer which can be interpreted as representing partially molten, possibly plume, material (Zorin et al., 1989). The age of the garnet peridotite locality is given as 13 Ma by Ashchepkov et al. (1994). Comparable geophysical data for the Lambert-Amery rift are lacking due to its remoteness. The Jetty Peninsula region is, however, positioned closer to the flanks of the rift than is the Vitim Plateau, although the unconfirmed possibility of Archean basement in the northern Prince Charles Mountains does not discount the possibility of a steeper increase in lithosphere thickness away from the rift relative to the Baikal rift.

The peridotites of both areas give comparable pressure-temperature estimates at or just below the spinel- to garnet lherzolite transition zone. Both xenolith suites bear evidence for reaction with infiltrating silicate melts: in the case of Bereya, this takes the form of infiltration textures and nonequilibrium trace element distributions, whereas the Jetty peridotites preserve major element zonation. Also preserved in the Antarctic peridotites is the progression from a lower pre-rift continental (but 
non-cratonic) geothermal gradient to a higher one typical of rifts shown by most xenoliths (Andronikov et al., 1998). This clearly demonstrates the increase in thermal gradient at the flanks of the rift, which is also manifested in episodes of melt infiltration showing the widening of asthenospheric influence by upward and outward migration of melt infiltration into the pre-existing lithosphere as the rift developed.

\section{Genesis of the alkali-picrite host magmas}

The coincidence of two non-cratonic garnet-bearing peridotite xenolith localities both with alkali picrites as the host magma type is intruiging. Furthermore, the peridotites of both areas contain evidence for melt infiltration probably associated with earlier episodes of rift activity. At least for the Bereya xenoliths, trace element modelling allows the infiltration to be attributed to an earlier episode of melt generation similar to the alkali picrite which later brought the xenoliths to the Earth's surface. These features appear ideal for the invocation of the vein-plus-wall-rock melting scenario suggested to be able to produce alkali picrites by Foley (1992). In this scenario, widening of the rift through time would produce repeated episodes of melting in the upwelling asthenosphere which would lead to veining of the underside of the lithosphere to progressively higher and more distal levels. During later episodes, veins formed in earlier episodes are reactivated due to their lower melting temperatures and the melts derived from the non-peridotitic vein assemblages react with the neighbouring wall-rock to produce a hybrid melt characterised by the incompatible element budget of the vein melt but the compatible, and to a large extent, major element budget of the wall-.rock. Furthermore, in the case of a propagating rift, as for a plume at the underside of stable continental lithosphere, a substantial proportion of melt can be expected to come from decompression melting of asthenospheric peridotite, which adds a third component to the hybrid melt mixture. The metasomatised peridotite samples do not themselves represent the vein material, but are infiltrated by melt of a similar origin to the magmatic rocks now hosting the xenoliths. The difference in $\mathrm{K}_{2} \mathrm{O} / \mathrm{Na}_{2} \mathrm{O}$ of the alkali picrites between the two regions is probably attributable to a higher proportion of mica relative to amphibole in the veins of the Vitim Plateau, whereas the high MgO contents of the alkali picrites show that extensive imput from asthenospheric melting must have occurred to dilute the strongly incompatible elementenriched initial vein melts. Propagating rifts and plume-influenced stable continental areas represent ideal situations for the production of alkali picrites by this mechanism, which require the melting of lithospheric veins contemporaneous with asthenospheric melting at relatively deep mantle levels.

\section{References}

Andronikov, A.V., Foley, S.F. and Melzer, S., 1998, Mantle xenoliths from the Jetty Peninsula area (East Antarctica): samples of thermally eroding lithosphere on the flanks of the Lambert-Amery Rift: 7th Int. Kimberlite Conf. Ext. Abs. (this volume)

Ashchepkov, I.V., 1991, Deep-seated inclusions at the Baikal Rift: Nauka, Novosibirsk, 160pp.

Ashchepkov, I.V., Litasov, Y.D. and Dobretsov, N.L., 1994, Pyroxenite and composite garnet peridotite xenoliths from picrite-basalt, Vitim Plateau (Transbaikal): implications for thermobarometry and mantle reconstruction: Proc. 5th Int. Kimberlite Conf. 1, 455-466.

Cao, R-L. and Zhu, S-H., 1987, Mantle xenoliths and alkali-rich host rocks in eastern China: in Nixon, P.H., ed., Mantle Xenoliths, J.Wiley, New York, 167-180.

Foley, S.F., 1992, Vein-plus-wall-rock melting mechanisms in the lithosphere and the origin of potassic alkaline magmas: Lithos 28, 435-453.

Glaser, S.M., Foley, S.F. and Günther, D., 1998, Trace element enrichment by melt infiltration in garnet- and spinel peridotite xenoliths from the Vitim volcanic field, Transbaikalia, eastern Siberia: Lithos Special Issue on Continental Roots, submitted.

Ionov, D.A., Ashchepkov, I.V., Stosch, H.-G., Witt-Eickschen, G. and Seck, H.A.,1993, Garnet peridotite xenoliths from the Vitim Volcanic Field, Baikal region: the nature of the garnet-spinel peridotite transition zone in the continental mantle: J.Petrol. 34, 1141-1175.

Stern, C.R., Saul, S., Skewes, M.A. and Futa, K., 1989, Garnet peridotite xenoliths from the PaliAike alkali basalts of southernmost South America: Proc. 4th Int. Kimberlite Conf. 2, 735-744.

Zorin, Y.A., Kozhevnikov, V.M., Novoselova, M.R. and Turutanov, E.K., 1989, Thickness of the lithosphere beneath the Baikal rift zone and the adjacent regions: Tectonophysics 168, 327-337. 